\title{
Three dimensional evaluation of upper airway volume in children with different dental and skeletal malocclusions
}

\author{
Kula, Katherine ${ }^{1}$, Ahn, Eun Jeong ${ }^{1}$, Halum, Stacey ${ }^{2}$, Dillehay, Kendall ${ }^{3}$, Ghoneima, Ahmed ${ }^{1,4}$ \\ 1. Department of Orthodontics, Indiana University School of Dentistry, Indianapolis, IN, USA. 2. Department of \\ Otolaryngology and Head-Neck Surgery, Indiana University School of Medicine, Indianapolis, IN, USA. 3. Private Practice, \\ Wichita, KS, USA. 4. Department of Orthodontics, Faculty of Dental Medicine, Al-Azhar University, Cairo, Egypt.
}

Correspondence: Ahmed Ghoneima. Address: Department of Orthodontics, Indiana University School of Dentistry, 1121 W. Michigan St., Indianapolis, IN. E-mail: aghoneim@iu.edu

Received: April 21, 2013

DOI : $10.5430 / j b g c . v 3 n 4 p 116$
Accepted: June 6, 2013

URL: http://dx.doi.org/10.5430/jbgc.v3n4p116

\section{Abstract}

Objective: The objectives of this retrospective study using cone beam computed tomography (CBCT) were to determine if there are differences in the volume of various upper airway segments and the most constricted area (MCA) of children with different dental and skeletal patterns.

Methods: The initial CBCTs of 83 orthodontic patients (Angle's Class I [ $n=30]$; Class II [ $n=26]$; and Class III [ $n=27]$ ) were collected from a private orthodontic office. Following reliability studies, various parameters of the craniofacial complex, airway volume, and MCA were measured utilizing Dolphin three-dimensional (3D) software. Comparisons among three dental and three skeletal malocclusions were performed using one-way ANOVA and Fishers Protected Least Significant. Associations of the airway volumes and the MCA with other parameters were determined using correlation coefficients, accepting $p \leq 0.05$ as significant for all tests.

Results: Maxillary right sinus volume was the only airway segment showing significant difference among different dental classes. Maxillary sinus volume also correlated moderately with anterior facial height and mandibular length. No significant differences were found between the MCA and different dentoskeletal classifications.

Conclusions: The only significant difference in airway parameters among the dental and skeletal malocclusions was that the dental Class II subjects had greater sinus volume than the other malocclusions. Shorter anterior facial height or mandibular length could be indicators for decreased airway volume in the sinus.

\section{Key words}

Cone beam computed tomography, Airway volume, Malocclusion

\section{Introduction}

Controversy concerning the relationship between facial morphology and airway volume or constriction is long standing ${ }^{[1]}$. While some studies ${ }^{[2,3]}$ report decreased volume of the lower airway with increased anterior posterior (AP) differential between the maxilla and mandible, other studies do not ${ }^{[4,5]}$. The shape of the airway is reported to be affected by skeletal 
discrepancy, but in different planes. AP dimensions of the airway were wider than transverse dimensions in Class III subjects compared with Class I or II subjects ${ }^{[3,4]}$ whereas the length of the airway was reported to be longer in leptoprosopic faces as compared with increased anteroposterior width in euryprosopic faces ${ }^{[3]}$.

Airway impairment can lead to mouth breathing and might contribute to long face as a result of increased airway resistance from nasal obstruction, adenotonsillar hypertrophy, and allergic rhinitis ${ }^{[6,7]}$. However, this effect might occur only in extreme cases ${ }^{[8]}$ most constricted area (MCA), rather than total or segmental airway volume, causes airflow turbulence and affects the efficiency of airflow ${ }^{[9]}$ and is an important factor in airway analyses. The association of significantly smaller MCA in subjects with obstructive sleep apnea (OSA) as compared to subjects without OSA is well reported ${ }^{[10,11]}$, but the association between the skeletal relationship and site of the MCA varies depending on the study ${ }^{[5,9]}$. Therefore, clarification of the relationship of airways and malocclusion is important in orthodontics.

The airway has been assessed with various imaging techniques including fluoroscopy, nasopharyngoscopy, cephalometry, computerized tomography (CT), cone beam computed tomography (CBCT), and magnetic resonance imaging (MRI ${ }^{[12,13]}$. A three-dimensional (3D) CBCT system provides more reliable landmark identification of the anatomical structures than two dimensional cephalometry ${ }^{[14-16]}$ allows precise measurement of airway space ${ }^{[17]}$ and can be used to locate the MCA of the airway ${ }^{[9]}$.

The purpose of this retrospective study using CBCT images of children was to determine if there were significant differences in the volume of the different airway segments (nasal cavity, nasopharynx, oropharynx, hypopharynx, maxillary sinuses), total airway, and the MCA among different dental and skeletal malocclusions. The second purpose was to determine if there were correlations between specific dental and skeletal parameters and airway parameters.

\section{Materials and methods}

This retrospective study was performed using CBCT images obtained from the routine initial records of 90 Phase I Caucasian orthodontic patients collected from one private practice in Kansas. Thirty subjects, classified according to Angle's classification using the AP relationship of the maxillary and mandibular permanent molars, were assigned to each Class I, Class II and Class III malocclusion group. With a sample size of 30 patients per malocclusion group, the study had $80 \%$ power to detect a 0.75 standard deviation difference between any two groups, assuming two-sided tests conducted at a $5 \%$ significance level. The total sample size of 90 subjects also provided $80 \%$ power to detect a correlation coefficient of .3 significantly different from zero. However, four Class II and three Class III subjects were excluded during initial examination of the images due to missing fourth cervical vertebra (CV4) in the image or blockage of the maxillary sinus reducing sample size to 30 Class I (20 F, 10 M), 26 Class II (18 F, 8 M), and 27 Class III (10 F, $17 \mathrm{M})$ subjects. The loss of subjects modified the power analysis slightly with a $79 \%$ power for the comparisons of the $n=30$ group vs. the $n=26$ group or the $\mathrm{n}=27$ group, $76 \%$ power for the $\mathrm{n}=26$ group vs. the $\mathrm{n}=27$ group, and still an $80 \%$ power to detect a correlation coefficient of .3 significantly different from zero.

Subject ages ranged from 5 years-13 years (Mean, 10 years 8 months \pm one year six months). The study was approved by the university Institutional Review Board. All medical histories showed no record of tonsillectomy or adenoidectomy. All CBCTs were taken with i-CAT CBCT (Imaging Sciences, Hatfield, PA) set for full $13 \mathrm{~cm}$ field of view, 20 seconds of scanning time, and a resolution of $0.4 \mathrm{~mm}$ voxel size.

The CBCT obtained for each individual was coded and randomly analyzed by the primary investigator who was blinded to the code. Analysis of the craniofacial complex was performed on the digital lateral cephalometric images created by Dolphin 3D software, version 11.0 (Dolphin Imaging, Chatsworth, CA) from the Digital Imaging and Communications in Medicine (DICOM) data of each individual. The cephalometric measurements were defined (see Table 1, Figure 1). Dental occlusion was confirmed for each side of all subjects using the CBCT volumetric rendering. Absence of sinus infection or obstruction was confirmed by checking the radiographic density of the sinuses with coronal slices prior to the measurement. The prevertebral soft tissue thickness was measured at different points along the airway to determine potential inflammatory increases among the groups.

Published by Sciedu Press 
Table 1. The cephalometric dentoskeletal measurements

\begin{tabular}{|c|c|}
\hline \multicolumn{2}{|r|}{ Skeletal measurements } \\
\hline SNA & $\begin{array}{l}\text { The angle formed by the intersection of the } \mathrm{S}-\mathrm{N} \text { to } \mathrm{N}-\mathrm{A} \text {, and defines the anteroposterior position of the } \\
\text { maxilla(A point) relative to the anterior cranial base. }\end{array}$ \\
\hline SNB & $\begin{array}{l}\text { The angle formed by the intersection of the } \mathrm{S}-\mathrm{N} \text { to } \mathrm{N}-\mathrm{B} \text {, and defines the anteroposterior position of the } \\
\text { mandible(B point) relative to the anterior cranial base. }\end{array}$ \\
\hline ANB & $\begin{array}{l}\text { The angle formed by the intersection of the A-N to N-B, and defines the relationship of the maxillary and } \\
\text { mandibular bases to each other in the sagittal plane. }\end{array}$ \\
\hline $\begin{array}{l}\text { Angle of convexity } \\
\text { (NA/APg) }\end{array}$ & $\begin{array}{l}\text { The angle formed by the intersection of the N-A-point to A-point - pogonion. It reveals the convexity (or } \\
\text { concavity) of the skeletal profile. }\end{array}$ \\
\hline Mandibular plane angle (MP/SN) & $\begin{array}{l}\text { The angle between mandibular plane and sella-nasion plane. It measures the cant of the mandibular plane in } \\
\text { relation to the cranial base. }\end{array}$ \\
\hline Palatal plane angle $(\mathrm{PP} / \mathrm{SN})$ & $\begin{array}{l}\text { The angle between the palatal planed and sella-nasion plane. It measures the cant of the palatal plane in } \\
\text { relation to the cranial base. }\end{array}$ \\
\hline Anterior cranial base length(N-S) & The linear distance from sella turcica and anterior point of the frontonasal suture. \\
\hline Midfacial length (Co-A point) & The linear distance from condylion to A-point. \\
\hline Mandibular body length (Co-Gn) & The linear distance from condylion and gnathion. \\
\hline $\mathrm{N}$ perp A point & $\begin{array}{l}\text { Anteroposterior position of the maxilla relative to the cranial base is determining by measuring the linear } \\
\text { distance between A-point and nasion perpendicular. }\end{array}$ \\
\hline $\mathrm{N} \perp \mathrm{Pg}$ & $\begin{array}{l}\text { Anteroposterior position of the mandible relative to the cranial base is determining by measuring the linear } \\
\text { distance from pogonion to the nasion perpendicular. }\end{array}$ \\
\hline N-ANS & $\begin{array}{l}\text { The vertical linear distance between nasion and anterior nasal spine. It measures the length of upper } \\
\text { anterior face height. }\end{array}$ \\
\hline ANS-Me & $\begin{array}{l}\text { The vertical linear distance between nasion and menton. It measures the length of the lower anterior face } \\
\text { height. }\end{array}$ \\
\hline $\mathrm{N}-\mathrm{Me}$ & $\begin{array}{l}\text { The vertical linear distance between nasion and menton. It measures the length of the total anterior facial } \\
\text { height. }\end{array}$ \\
\hline S-Go & The vertical linear distance between sella and gonion. It measures the length of the posterior facial height. \\
\hline \multicolumn{2}{|r|}{ Dental measurements } \\
\hline Maxillary incisor to $\mathrm{SN}(1 / \mathrm{SN})$ & The angle formed between the long axis of maxillary central incisor and the anterior cranial base. \\
\hline $\begin{array}{l}\text { Mandibular incisor to mandibular plane } \\
\text { (/1MP) }\end{array}$ & The angle formed between long axis of mandibular central incisor and the mandibular plane. \\
\hline $\begin{array}{l}\text { Wits appraisal } \\
(\mathrm{AO}-\mathrm{BO})\end{array}$ & $\begin{array}{l}\text { The linear distance between the perpendicular lines from point A and B on the maxilla and mandible, } \\
\text { respectively, onto the occlusal plane, which is drawn through the region of maximum cuspal } \\
\text { interdigitation. }\end{array}$ \\
\hline Overjet & $\begin{array}{l}\text { The horizontal distance between the incisal tips of the maxillary and mandibular incisors measured } \\
\text { perpendicular to the facial plane. }\end{array}$ \\
\hline Overbite & $\begin{array}{l}\text { The vertical distance between the incisal tips of the maxillary and mandibular incisors measured } \\
\text { perpendicular to the facial plane. }\end{array}$ \\
\hline
\end{tabular}

Figure 1. Cephalometric measurements: 1. $\mathrm{SNA}^{\circ} ; 2 . \mathrm{SNB}^{\circ} ; 3 . \mathrm{ANB}^{\circ} ; 4$. Angle of convexity (NA - APg) $)^{\circ}$ 5. Mandibular plane angle (MP-SN) ${ }^{\circ}$; 6. Palatal plane angle $(\mathrm{PP}-\mathrm{SN})^{\circ}$; 7. Inclination of maxillary central incisor $(1 /-\mathrm{SN}){ }^{\circ} ; 8$. Inclination of mandibular central incisor $(/ 1-\mathrm{MP})^{\circ}$; 9. Anterior cranial base length $(\mathrm{N}-\mathrm{S}) ; \quad$ 10.Midfacial length (Co-A); 11.Mandibular body length $(\mathrm{Co}-\mathrm{Gn}) ; 12 . \mathrm{N} \perp$ A point; $13 . \mathrm{N} \perp \mathrm{Pg}$; 14.N-ANS; 15.ANS-Me; 16.N-Me; 17.S-Go; 18.Wits appraisal (AO-BO); 19.Overjet; 20.Overbite.
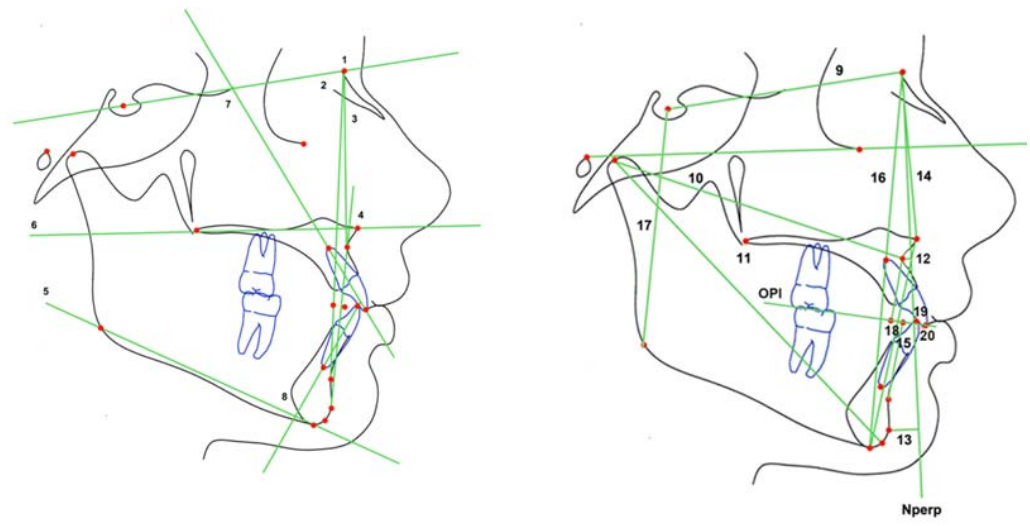
The airway volume and the MCA were evaluated using the same software on the 3D images of the airway. All 3D volumetric images were oriented in Dolphin imaging software as follows: the midsagittal plane aligned to the midline of the face, the axial plane aligned to the level of Frankfurt horizontal (FH) plane (Po-Or) parallel to the floor, and the coronal plane aligned to the level of the furcation point of the right maxillary first molar (see Figure 2). The boundaries of each airway segment, the MCA, and the prevertebral soft tissue thickness were defined (see Table 2, Figure 3 and Figure 4A). Subjects were reclassified into skeletal malocclusion based on division of ANB angle: Class 1 (2 degrees- 4 degrees); Class 2 ( $>4$ degrees); Class 3 ( $<2$ degrees). Since AP skeletal discrepancies based on ANB alone do not identify which jaw is causing the discrepancy, specific cephalometric parameters were identified to determine if there was an association with airway parameters.

Table 2. The boundaries of each airway segment, the most constricted area of the airway, and the prevertebral soft tissue thickness (see Figure 3 and Figure 4)

\begin{tabular}{|c|c|c|}
\hline The airway segments & Plane & Boundaries \\
\hline The nasal cavity & $\begin{array}{l}\text { Sagittal } \\
\text { plane }\end{array}$ & $\begin{array}{l}\text { Anterior: by the line connecting the anterior nasal spine (ANS) - the tip of the nasal bone - } \\
\text { Nasion (N) } \\
\text { Posterior: the line extending from Sella point (S) - Posterior nasal spine (PNS) } \\
\text { Superior: the line connecting the N-S } \\
\text { Inferior: the line extending from ANS -PNS } \\
\text { the outline of the nasal cavity in a section including the maxillary first molar bifurcaction area } \\
\text { starting at the crista galli, running downward toward the nasal floor and passing through the } \\
\text { sidewalls of the right and left nasal cavity }\end{array}$ \\
\hline The nasopharynx & $\begin{array}{l}\text { Sagittal } \\
\text { plane }\end{array}$ & $\begin{array}{l}\text { Anterior: the line extending from S -PNS } \\
\text { Posterior: the line extending from S - tip of the odontoid process } \\
\text { Inferior: the line extending from PNS - tip of the odontoid process }\end{array}$ \\
\hline The oropharynx & $\begin{array}{l}\text { sittal } \\
\text { ne }\end{array}$ & $\begin{array}{l}\text { Anterior: the line extending from PNS - base of the epiglottis } \\
\text { Posterior: the line extending from the tip of the odontoid process - posterior-superior border of } \\
\text { C4 } \\
\text { Superior: the line extending from PNS - tip of the odontoid process } \\
\text { Inferior: the line extending from the posterior-superior border of C4- the base of the epiglottis - } \\
\text { symphysis of the mandible }\end{array}$ \\
\hline The hypopharynx & $\begin{array}{l}\text { Sagittal } \\
\text { plane }\end{array}$ & $\begin{array}{l}\text { Anterior: the line extending from the base of the epiglottis - symphysis of the mandible } \\
\text { Posterior: the line extending from the posterior-superior corner of } \mathrm{C} 4 \text {-posterior-inferior corner } \\
\text { of } \mathrm{C} 4 \\
\text { Superior: the line extending from the posterior-superior corner of } \mathrm{C} 4 \text {-the base of the epiglottis - } \\
\text { symphysis of the mandible }\end{array}$ \\
\hline $\begin{array}{l}\text { The maxillary sinus } \\
\text { volume }\end{array}$ & $\begin{array}{l}\text { Coronal } \\
\text { plane }\end{array}$ & $\begin{array}{l}\text { Inferior: the line extending from the posterior-inferior corner of } \mathrm{C} 4 \text {-symphysis of the mandible } \\
\text { the outline of the maxillary sinus in a section including the maxillary first molar bifurcation } \\
\text { areas starting at the molar bifurcation areas, running along the lateral, superior, medial and } \\
\text { inferior borders of the sinus }\end{array}$ \\
\hline $\begin{array}{l}\text { Total airway and the } \\
\text { boundary to detect the } \\
\text { most constricted area } \\
\text { of the airway }\end{array}$ & $\begin{array}{l}\text { Sagittal } \\
\text { plane }\end{array}$ & $\begin{array}{l}\text { Anterior: the line extending from } \mathrm{S} \text {-PNS - symphysis of mandible } \\
\text { Posterior: the line extending from } \mathrm{S} \text { - the tip of the odontoid process - posterior-superior border } \\
\text { of } \mathrm{C} 4 \\
\text { Inferior: the line extending from the posterior-superior border of } \mathrm{C} 4 \text { - symphysis of the } \\
\text { mandible }\end{array}$ \\
\hline $\begin{array}{l}\text { The prevertebral soft } \\
\text { tissue thickness as } \\
\text { distance parallel to } \mathrm{FH} \\
\text { plane from } 6 \text { points }\end{array}$ & $\begin{array}{l}\text { Sagittal } \\
\text { plane }\end{array}$ & $\begin{array}{l}\text { The most anterior point on the anterior arch of the atlas vertebrae (AA) } \\
\text { The most inferior-anterior point of CV2 (CV2ia) } \\
\text { The most superior-anterior point of CV3 (CV3sa) } \\
\text { The most inferior-anterior point of CV3 (CV3ia) } \\
\text { The most superior-anterior point of CV4 (CV4sa) } \\
\text { The most inferior-anterior point of CV4 (CV4ia) }\end{array}$ \\
\hline
\end{tabular}


Figure 2. Image orientation along the midsagittal, axial and coronal planes.
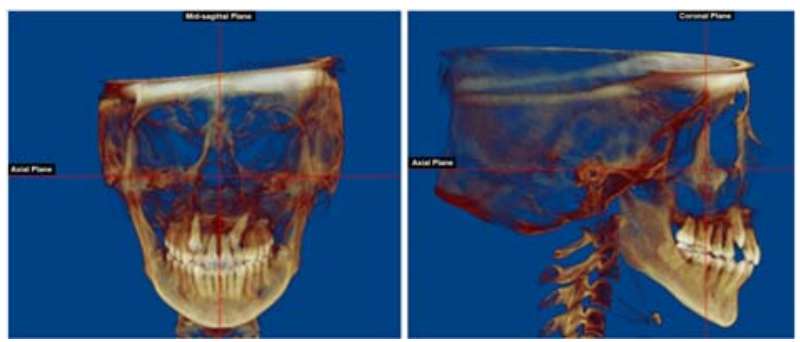

Figure 3. A) Airway segments: A. Nasal Cavity; B. Nasopharynx; C. Oropharynx; D. Hypopharynx. 21. Sella; 22. PNS; 23. ANS; 24. The tip of the nasal bone; 25.Nasion; 26. Crista galli; 27. Tip of the odontoid process; 28. The posterior-superior corner of CV4; 29.Base of the epiglottis; 30.Symphysis of mandible; 31 . The posterior-inferior corner of C4; B) Right and left maxillary sinuses; C) Total airway volume and location of the most constricted area.

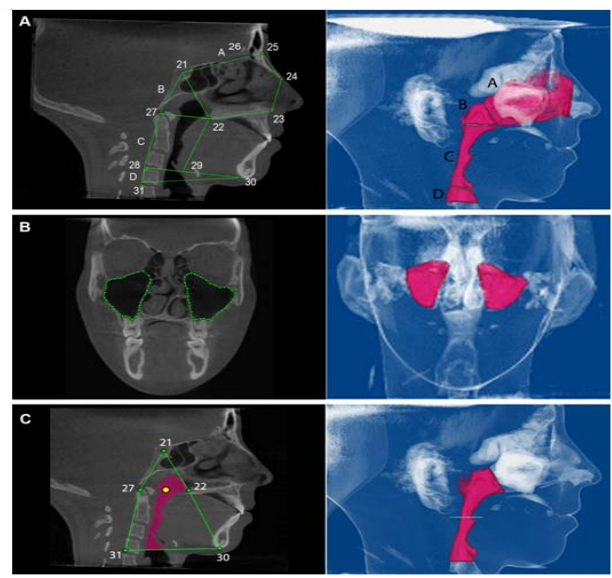

Intrarater reliability measures were conducted by the primary investigator at the start of the study using CBCT images of 10 randomly selected patients who were not in this study. All the records were coded and randomized. Dentoskeletal parameters, airway volumes, the MCA, and the prevertebral soft tissue thickness of the airway were identified and measured using Dolphin 3D imaging software. These measurements were repeated with a two week interval.

Intraclass correlation coefficients (ICCs) and Bland-Altman plots were used to assess the intrarater reliability; systemic error was evaluated using student's $t$-test.

Comparisons among the three dental and the three skeletal classes were performed using analysis of covariance. Because the parameters may be affected by age and gender, these two factors were included in the analyses as covariates. Fisher's Protected Least Significant Differences method was used to control the overall significance level of the pair-wise tests at $5 \%$. The correlations between the various cephalometric parameters and the airway segments were analyzed and adjusted for age and sex. The difference in the location of the MCA among the three dental and skeletal classes was analyzed at four different levels: nasopharynx, upper oropharynx, lower oropharynx, and hypopharynx (see Figure 4B). Comparisons were made using Mantel-Haenszel chi-square tests. Significant was accepted at $p \leq .05$ for all tests.

Figure 4. A) Prevertebral soft tissue thickness at CV1, CV2, CV3, and CV4. 32. the most anterior point of atlas vertebrae (AA); 33. The most inferior-anterior point of CV2 (CV2ia); 34. The most superior-anterior point of CV3 (CV3sa); 35. The most inferior-anterior point of CV3 (CV3ia); 36. The most superior-anterior point of CV4 (CV4sa); 37. The most inferior-anterior point of CV4 (CV4ia); B) Airway levels for the location of the
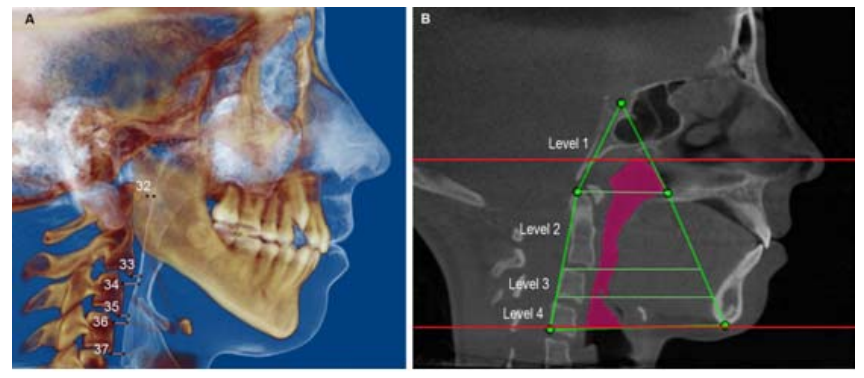
most constricted area of the airway. 


\section{Results}

Intrarater reliability was considered excellent (all ICCs between the two readings were $\geq .95$ ). No statistically significant difference $(p \leq .05)$ existed between the two readings except for three values (NS, AOBO, and CV4ia). The maximum discrepancy of these three values was $0.3 \mathrm{~mm}$ which would not be significant clinically.

Means and standard deviations for each parameter by dental malocclusion class are presented in Table 3. The only significantly different parameters found among the dental malocclusions were SNB, ANB, NS, CoA, AOBO, NA/APg, $\mathrm{N} \perp \mathrm{Pg}, \mathrm{OB}$, and $\mathrm{OJ}$, and maxillary right sinus volume. The cephalometric parameters showing significant AP differences among the groups were expected based on dental classification. Maxillary right sinus volume was the only airway segment showing significant differences with larger volume in dental Class II than Class I or Class III. However, when the volumes of the two sinuses were grouped, there were no significant differences among the classes. No airway parameter was significantly different $(p>.05)$ among the skeletal classes.

Females had significantly $(p=.03)$ larger maxillary sinus volumes $\left(17,261 \mathrm{~mm}^{3} \pm 728 \mathrm{~mm}^{3}\right)$ than males $\left(15,186 \mathrm{~mm}^{3} \pm\right.$ $\left.1,129 \mathrm{~mm}^{3}\right)$. Males had significantly $(p=.02)$ thicker prevertebral soft tissue thickness at CV2 $(4.9 \mathrm{~mm} \pm 0.2 \mathrm{~mm})$ than females $(4.4 \mathrm{~mm} \pm 0.1 \mathrm{~mm})$. But females had thicker $(p=.05)$ tissues at CV4ia $(8.5 \mathrm{~mm} \pm 0.5 \mathrm{~mm})$ than males $(7.0 \mathrm{~mm} \pm$ $0.5 \mathrm{~mm})$. Age showed significant, but weak, associations only with nasal cavity volume $(r=.28 ; p=.01)$, maxillary sinus volume $(r=.37 ; p=.00)$, and significant negative associations with CV4ia thickness $(r=-.02 ; p=.05)$. There were significant increases in nasal cavity volume $(p=.04)$ and maxillary sinus volume $(p=.01)$ with age. Correlations of the different skeletal and dental parameters with the airway parameters indicated significant but weak to moderate associations between many of the measurements (see Table 4). Moderate correlations ( $>.40$ ) existed only between total sinus volumes and anterior facial height (N-Me) and mandibular length (Co-Gn).

No significant differences in MCA size or location were found among the dental classes $(p=.97)$ or skeletal classes $(p=.15)$ (see Table 3, Figure 5). The MCA was not located in the same airway level even within the same dental malocclusion group (see Table 5).

Table 3. Comparison between the skeletal, dental, and airway parameters based on dental classification groups

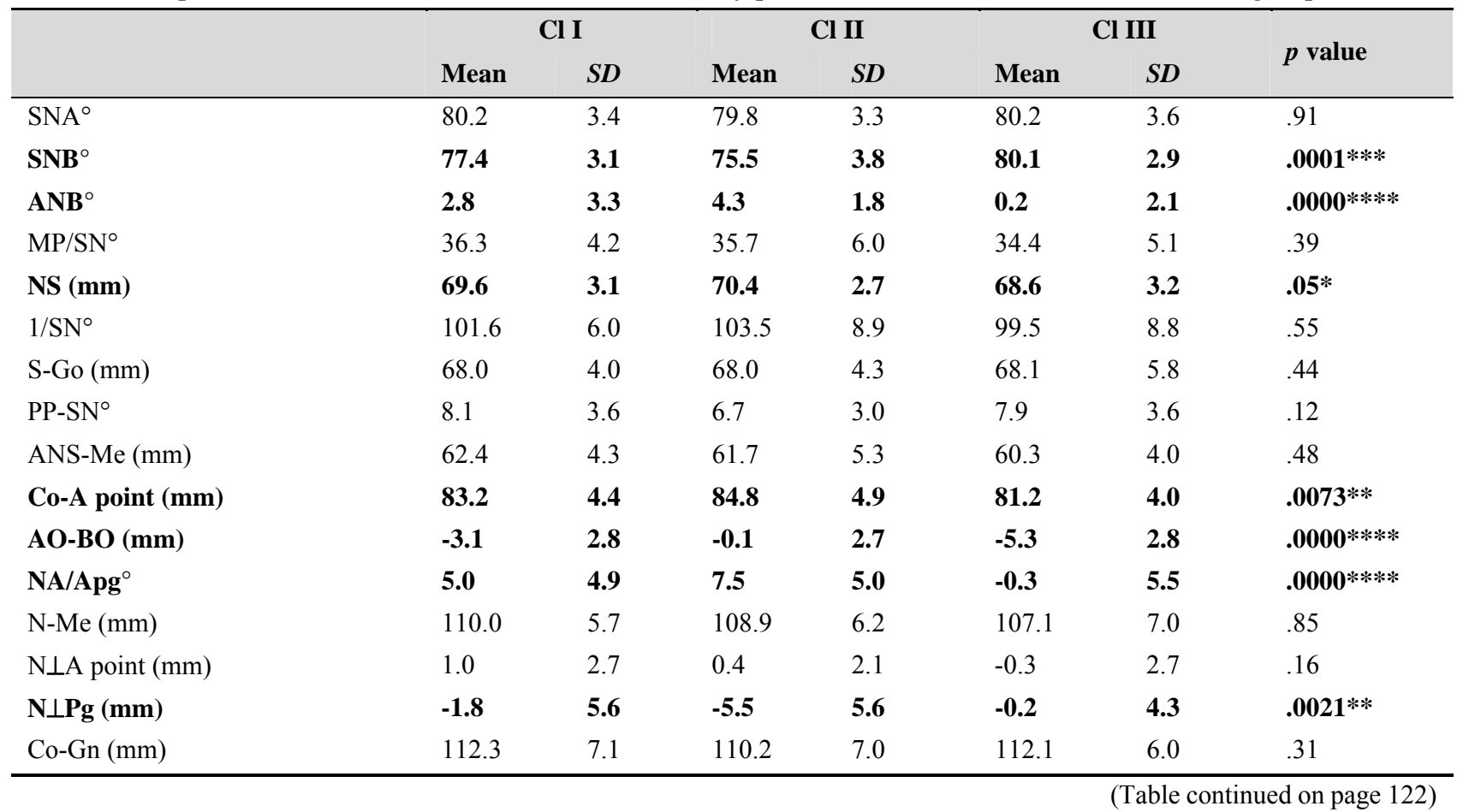


Table 3. (continued.)

\begin{tabular}{|c|c|c|c|c|c|c|c|}
\hline & \multicolumn{2}{|c|}{ Cl I } & \multicolumn{2}{|c|}{ CI II } & \multicolumn{2}{|c|}{ Cl III } & \multirow{2}{*}{$p$ value } \\
\hline & Mean & $S D$ & Mean & $S D$ & Mean & $S D$ & \\
\hline $\mathrm{MP} / 1^{\circ}$ & 84.0 & 6.0 & 86.0 & 6.1 & 81.7 & 6.8 & .10 \\
\hline OB (mm) & 3.3 & 2.8 & 4.3 & 2.1 & 1.4 & 1.8 & $.0074 * *$ \\
\hline OJ (mm) & 3.9 & 1.5 & 6.9 & 2.4 & -0.7 & 2.7 & $.0000 *$ \\
\hline N-ANS (mm) & 48.9 & 3.4 & 48.9 & 2.3 & 47.9 & 3.9 & .91 \\
\hline Nasal Cavity Volume $\left(\mathrm{mm}^{3}\right)$ & 11,110 & 2,725 & 11,191 & 2,244 & 10,338 & 2,930 & .90 \\
\hline Nasopharynx Volume $\left(\mathrm{mm}^{3}\right)$ & 3,207 & 1,222 & 3,257 & 1,333 & 3,070 & 1,206 & .95 \\
\hline Oropharynx Volume $\left(\mathrm{mm}^{3}\right)$ & 8,511 & 2,546 & 9,622 & 3,616 & 8,945 & 3,069 & .34 \\
\hline Hypopharynx Volume $\left(\mathrm{mm}^{3}\right)$ & 600 & 354 & 676 & 529 & 681 & 448 & .81 \\
\hline Maxillary R Sinus Volume $\left(\mathrm{mm}^{3}\right)$ & 7,796 & 2,694 & 9,320 & 2,936 & 6,728 & 2,867 & $.0308 *$ \\
\hline Maxillary L Sinus Volume $\left(\mathrm{mm}^{3}\right)$ & 8,417 & 2,791 & 9,755 & 3,208 & 7,260 & 2,744 & .25 \\
\hline Maxillary Sinus Volume $\left(\mathrm{mm}^{3}\right)$ & 16,213 & 5,304 & 19,075 & 5,940 & 13,988 & 5,397 & .11 \\
\hline Total Airway Volume $\left(\mathrm{mm}^{3}\right)$ & 12,907 & 3,544 & 14,301 & 2,995 & 13,220 & 4,205 & .33 \\
\hline Most Constricted Area $\left(\mathrm{mm}^{2}\right)$ & 111 & 46.3 & 113 & 47.1 & 113 & 49.1 & .68 \\
\hline $\mathrm{AA}(\mathrm{mm})$ & 6.9 & 3.4 & 7.3 & 4.4 & 7.9 & 3.8 & .95 \\
\hline $\mathrm{CV} 2(\mathrm{~mm})$ & 4.6 & 0.7 & 4.4 & 0.9 & 4.9 & 1.1 & .55 \\
\hline CV3sa (mm) & 5.0 & 0.6 & 5.3 & 1.1 & 5.0 & 1.0 & .40 \\
\hline CV3ia (mm) & 4.8 & 1.4 & 4.7 & 1.1 & 4.9 & 1.0 & .76 \\
\hline CV4sa (mm) & 6.2 & 2.1 & 6.4 & 2.6 & 6.3 & 2.1 & .92 \\
\hline CV4ia (mm) & 7.6 & 3.0 & 7.9 & 3.5 & 8.1 & 3.5 & 1.00 \\
\hline
\end{tabular}

$\mathrm{CL}=$ Class $\quad S D=$ standard deviation $\quad \mathrm{mm}=$ millimeter $\quad{ }^{\circ}$ Degree

Significance levels $\left(P=0.05^{*} ; P=0.01^{* *} ; P=0.001^{* * *} ; P=0.0001^{* * * *}\right)$

Table 4. Significant correlation coefficient between skeletal or dental parameters and airway parameters in all subjects

\begin{tabular}{lll}
\hline & Correlation $(\boldsymbol{r})$ & $\boldsymbol{p}$-value \\
\hline MP/SN vs. Nasopharynx Volume & -.23 & $.0384^{*}$ \\
S-Go vs. Maxillary Sinus Volume & .25 & $.0254^{*}$ \\
ANS-Me vs. Nasopharynx Volume & -.26 & $.0194^{* *}$ \\
ANS-Me vs. Oropharynx Volume & .23 & $.0395^{*}$ \\
ANS-Me vs. Maxillary Sinus Volume & .35 & $.0011^{* *}$ \\
Co-A point vs. Nasal Cavity Volume & .27 & $.0154^{*}$ \\
Co-A point vs. Maxillary Sinus Volume & .35 & $.0014^{* *}$ \\
AO-BO vs. Nasal Cavity Volume & .23 & $.0410^{*}$ \\
N-Me vs. Nasal Cavity Volume & .27 & $.0159^{*}$ \\
N-Me vs. Nasopharynx Volume & -.26 & $.0183^{*}$ \\
N-Me vs. Oropharynx Volume & .22 & $.0489^{*}$ \\
N-Me vs. Maxillary Sinus Volume & .41 & $.0001^{* *}$ \\
Co-Gn vs. Maxillary Sinus Volume & .44 & $.0000^{* *}$ \\
MP/1 vs. CV4sa & .25 & $.0252^{*}$ \\
OB vs. Nasopharynx Volume & .23 & $.0372^{*}$ \\
N-ANS vs. Nasal Cavity Volume & .30 & $.0069^{* *}$ \\
N-ANS vs. Maxillary Sinus Volume & .31 & $.0047^{* *}$ \\
\hline
\end{tabular}

* Correlation significant at 0.05 level

** Correlation significant at 0.01 level 
Figure 5. The most constricted area of the airway based on dental and skeletal classes.

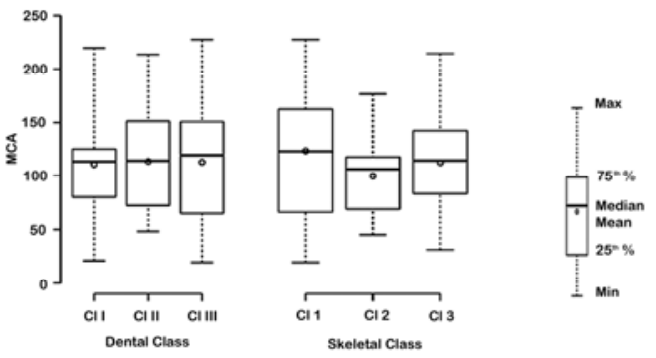

Table 5. The location of the most constricted area among the dental malocclusions

\begin{tabular}{|c|c|c|c|c|}
\hline & Airway level & Cl I $(n=30)$ & Cl II (n = 26) & Cl III (n = 27) \\
\hline Level $1(n=2)$ & Area between the superior and inferior borders of nasopharynx & 0 & 2 & 0 \\
\hline Level $2(n=38)$ & $\begin{array}{l}\text { Area from inferior border of nasopharynx to the level of CV2ia } \\
\text { (Upper oropharynx) }\end{array}$ & 16 & 9 & 13 \\
\hline Level $3(n=15)$ & $\begin{array}{l}\text { Area form the level of CV2ia to superior border of } \\
\text { hypopharynx (Lower oropharynx) }\end{array}$ & 4 & 4 & 7 \\
\hline Level $4(n=28)$ & $\begin{array}{l}\text { Area between the superior and inferior borders of } \\
\text { hypopharynx }\end{array}$ & 10 & 11 & 7 \\
\hline
\end{tabular}

\section{Discussion}

The relationship between dental features and the airway volume has been controversial for decades. 2D studies ${ }^{[16,17]}$ showed no or weak association between a dental Class I or II occlusion and nasopharyngeal area. The study by Tourne ${ }^{[1]}$ suggested that nasopharyngeal structure had minimal effect on AP facial dimensions in seemingly healthy individuals. Our study found no significant differences in upper airway segments in children with dental malocclusions except for the right maxillary sinus. However, this difference disappeared when the volumes of both sinuses were considered together. The measurement of sinus volumes using Dolphin software is a measurement of air volume only, not actual sinus volume. The differences between the two sides could be attributed to differences of the mucosal membrane thicknesses with one sinus being more affected than another. Another explanation of the difference in sinus air volume could be related to the deviation of the nasal septum consistently to one side could be associated with a smaller sinus volume, but nasal septal deviation was not analyzed in this study. When the malocclusions were redefined based on AP relationship of the skeleton, there were no significant differences in our subjects. Thus the findings of our study confirm a $2 \mathrm{D}$ study ${ }^{[18]}$ which reported no association between sagittal skeletal malocclusions and sinus volume in 14 year old Japanese adolescents.

Conflicting results have been reported related to skeletal morphology and the airway. Although a negative correlation between AP skeletal discrepancy (using ANB and AO-BO) and the airway volume was reported ${ }^{[2,3]}$, our study found that anterior facial height (NMe) was negatively correlated with nasopharynx volume. Other studies with adults found no difference between skeletal AP discrepancy (ANB) and airway volume ${ }^{[4,5]}$. Our results also showed that some parameters representing skeletal AP discrepancies, such as AOBO, maxillary length, and mandibular length, were positively correlated, although weakly, to maxillary sinus or nasal cavity, but not to the nasopharynx or the oropharynx. This correlation is understandable since volume of a space such as the maxillary sinus and the nasal cavity is related to the length and height of the space.

Similar to 2D studies ${ }^{[19,20]}$, our 3D study of healthy children did not show significant differences in upper or lower pharyngeal airways with dental or skeletal malocclusion. Although increased mandibular plane did correlate with a decreased nasopharyngeal volume, the strength of the association was weak. 
Maxillary sinus volume is associated with the development of the maxilla ending in the second decade for females and the third decade for males ${ }^{[18]}$. The increase in volume can be affected by both the vertical and sagittal growth of the maxilla. In agreement with the study on adolescents by Freitas et al ${ }^{[20]}$, maxillary sinus size and nasal cavity volume had no significant association among different skeletal classifications based on ANB although both studies show that results were affected by subject age. Contrary to the study by Paul and Nanda ${ }^{[21]}$ with adult females reporting that the form of the maxillary sinus was influenced by anteroposterior facial dimension (SNA) rather than vertical dimension, our results showed that the maxillary sinus volume is correlated to both the vertical and AP skeletal parameters. The moderate correlations of sinus volume with anterior facial height might be explained by vertical growth of the maxilla and alveolar processes with age. The response of the mandible to vertical growth of the maxilla would be downward displacement causing increased total anterior facial height and strengthening the correlation of the maxillary sinus volume with total anterior facial height. The differences between studies might be explained by the limited accuracy of measurement of sinus and nasal cavity using 2D radiographs as compared with 3D radiographs. Subject age differences also could contribute to the discrepant results between studies.

The gender difference in our study might be explained by the early completion of facial and vertebral growth by females within our subject age group as compared to males. However, when the genders are factored into statistical analysis, our study found no difference in 3D airway volumes by dental malocclusion.

Mandibular position in mandibular prognathic girls ${ }^{[22]}$ could influence the hypopharynx airway space, though we did not find any significant difference in MCA size with different AP skeletal pattern or by gender. This difference again could be related to patient selection. In agreement with our study, mandibular plane angle was negatively correlated with nasopharyngeal airway space ${ }^{[23]}$. These results could be explained if the soft palate was pushed backward or upward by the tongue with increased clockwise rotation of the mandible.

Other factors could impact the MCA. Obesity or accumulated fat in the neck region are associated with increased collapse of the upper airway in both apneic and nonapneic subjects ${ }^{[24]}$. Asthma or allergy can also narrow the airway through airway wall thickening ${ }^{[25]}$. Chronic rhinosinusitis can decrease maxillary sinus volume by maxillary mucosal thickening ${ }^{[26]}$.

Since body mass index and history of rhinosinusitis was not available for our subjects, prevertebral soft tissue thickness was included in this study. Our results showed no significant difference of the prevertebral soft tissue thickness among different dental malocclusions and no correlation with dentoskeletal parameters.

The MCA in adults without OSA averaged $146.9 \mathrm{~mm}^{2}$ while in OSA patients in a supine position the minimum cross section averaged $45.8 \mathrm{~mm}^{2}{ }^{[27]}$. The location of the MCA in all of these adults was in the retropalatal region and was probably related to the supine position during the acquisition of the radiograph. The uvula probably fell posteriorly. Our study did not find any MCA differences among the different dental or skeletal classes of healthy children. Mean MCA of our study was over $100 \mathrm{~mm}^{2}$ though three subjects had smaller MCA than $45.8 \mathrm{~mm}^{2}$. These smallest MCAs occurred in one Class I subject ( 12 years two months, F) in the upper part of the oropharynx, while the other Class I subject (10 years seven months, M) was constricted in the lower part of the oropharynx, and a Class III patient (9 years one month, M) was constricted in the hypopharynx.

The location of the MCA is considered important ${ }^{[13,19]}$. With 2D cephalometry, pharyngeal constriction was measured AP at two levels: behind the uvula for the upper part of the airway and at the intersection of posterior border of the tongue and inferior border of the mandible for the lower part of the upper airway ${ }^{[20]}$. A 3D study reported that the MCA occurred dorsal to the posterior tongue ${ }^{[9]}$. Our study showed that the MCA location varied with a tendency to occur most often at the upper part of the oropharynx followed by the hypopharynx. The nasopharynx was the least most common area although enlarged adenoids were expected as the greatest adenoid volume was reported in children under 10 years old ${ }^{[28]}$. 
The limitations of this retrospective radiographic study of orthodontic patients include the lack of controls or subjects without malocclusions. Unfortunately, 3D CBCTs are not taken standardly in an orthodontic office of patients without malocclusions. Radiographs for orthodontic subjects are usually taken of subjects in an upright position and not supine as when sleeping. This makes interpretation of airways for purposes of sleep apnea prediction difficult. In addition, body mass index was not available to determine its effect on airway size. However, body mass index would probably have no effect on the maxillary sinuses which were constrained by bone and probably minimal effect on the nasopharynx which is also constrained by bone and cartilage.

In conclusion, no significant differences were found between the different segments of the airway volume or size or location of the most constricted area of the airway among different malocclusions except for the maxillary sinus volume. Moderate correlation existed between the sinus volumes and the anterior facial height and the mandibular length. A longitudinal study to determine changes in airway measures as well as development of symptoms of sleep breathing disorders might facilitate prediction of future problems.

\section{Acknowledgment}

This study was funded by the 3D imaging of the Craniofacial Complex Center- IUPUI and Jarabak Professorship. The authors would also like to thank George Eckert for statistical assistance.

\section{References}

[1] Tourne LP. Growth of the pharynx and its physiologic implications. Am J Orthod Dentofacial Orthop. [Internet] 1991; 99: 129-139. Available from: http://www.ajodo.org/article/0889-5406(91)70115-D. http://dx.doi.org/10.1016/0889-5406(91)70115-D

[2] Grauer D, Cevidanes LS, Styner MA, Ackerman JL, Proffit WR. Pharyngeal airway volume and shape from cone-beam computed tomography: relationship to facial morphology. Am J Orthod Dentofacial Orthop. [Internet] 2009; 136: 805-814. PMid: 19962603. Available from: http://www.ncbi.nlm.nih.gov/pmc/articles/PMC2891076/. http://dx.doi.org/10.1016/j.ajodo.2008.01.020

[3] Iwasaki T, Hayasaki H, Takemoto Y, Kanomi R, Yamasaki Y. Oropharyngeal airway in children with Class III malocclusion evaluated by cone-beam computed tomography. Am J Orthod Dentofacial Orthop. [Internet] 2009; 136: 318 e311-319; discussion 318-319. Available from: http://www.ajodo.org/article/S0889-5406(09)00511-3

[4] Kikuchi Y. Three-dimensional relationship between pharyngeal airway and maxillo-facial morphology. Bull Tokyo Dent Coll. [Internet] 2008; 49: 65-75. PMid: 18776718. Available from: http://ir.tdc.ac.jp/irucaa/bitstream/10130/569/1/49_65.pdf. http://dx.doi.org/10.2209/tdcpublication.49.65

[5] Alves PV, Zhao L, O'Gara M, Patel PK, Bolognese AM. Three-dimensional cephalometric study of upper airway space in skeletal class II and III healthy patients. J Craniofac Surg. [Internet] 2008; 19: 1497-1507. PMid: 19098539. Available from:http://journals.lww.com/jcraniofacialsurgery/pages/articleviewer.aspx?year=2008\&issue=11000\&article=00012. http://dx.doi.org/10.1097/SCS.0b013e31818972ef

[6] Rafael R. Nasopharyngeal obstruction as a cause of malocclusion. Pract Odontol. [Internet] 1990; 11: 11-15, 17, 19-20 passim. PMid: 2132279. Available from: http://www.ncbi.nlm.nih.gov/pubmed/2132279

[7] Smith RM, Gonzalez C. The relationship between nasal obstruction and craniofacial growth. Pediatr Clin North Am. [Internet] 1989; 36: 1423-1434. PMid: 2587086. Available from: http://europepmc.org/abstract/MED/2587086

[8] Vig KW. Nasal obstruction and facial growth: the strength of evidence for clinical assumptions. Am J Orthod Dentofacial Orthop. [Internet] 1998; 113: 603-611. Available from: http:/www.ajodo.org/article/S0889-5406(98)70219-7. http://dx.doi.org/10.1016/S0889-5406(98)70219-7

[9] Tso HH, Lee JS, Huang JC, Maki K, Hatcher D, Miller AJ. Evaluation of the human airway using cone-beam computerized tomography. Oral Surg Oral Med Oral Pathol Oral Radiol Endod. [Internet] 2009; 108: 768-776. PMid: 19716716. Available from: http://www.journals.elsevierhealth.com/periodicals/ymoe/article/S1079-2104(09)00365-5/pdf. http://dx.doi.org/10.1016/j.tripleo.2009.05.026

[10] Ryan CF, Lowe AA, Li D, Fleetham JA. Three-dimensional upper airway computed tomography in obstructive sleep apnea. A prospective study in patients treated by uvulopalatopharyngoplasty. Am Rev Respir Dis. [Internet] 1991; 144: 428-432. PMid: 1859072. Available from: http://www.ncbi.nlm.nih.gov/pubmed/1859072. http://dx.doi.org/10.1164/ajrccm/144.2.428 
[11] Avrahami E, Solomonovich A, Englender M. Axial CT measurements of the cross-sectional area of the oropharynx in adults with obstructive sleep apnea syndrome. AJNR Am J Neuroradiol. [Internet] 1996; 17: 1107-1111. PMid: 8791923. Available from: http://www.ajnr.org/content/17/6/1107.long

[12] Fredberg JJ, Wohl ME, Glass GM, Dorkin HL. Airway area by acoustic reflections measured at the mouth. J Appl Physiol. [Internet] 1980; 48: 749-758. PMid: 7451282. Available from: http://jap.physiology.org/content/48/5/749.full.pdf

[13] Sorensen H, Solow B, Greve E. Assessment of the nasopharyngeal airway. A rhinomanometric and radiographic study in children with adenoids. acta Otolaryngol. [Internet] 1980; 89: 227-232. Available from: http://www.ncbi.nlm.nih.gov/pubmed/7395494

[14] Brown AA, Scarfe WC, Scheetz JP, Silveira AM, Farman AG. Linear accuracy of cone beam CT derived 3D images. Angle Orthod. [Internet] 2009; 79: 150-157. PMid: 19123719. Available from: http://www.angle.org/doi/pdf/10.2319/122407-599.1. http://dx.doi.org/10.2319/122407-599.1

[15] Chien P, Parks E, Eraso F, Hartsfield J, Roberts W, Ofner S. Comparison of reliability in anatomical landmark identification using two-dimensional digital cephalometrics and three-dimensional cone beam computed tomography in vivo. Dentomaxillofac Radiol. [Internet] 2009; 38: 262-273. PMid: 19474253. Available from: http://dmfr.birjournals.org/content/38/5/262.full.pdf+html. http://dx.doi.org/10.1259/dmfr/81889955

[16] Kerr WJ. The nasopharynx, face height, and overbite. Angle Orthod. [Internet] 1985; 55: 31-36. PMid: 3856405. Available from: http://www.angle.org/doi/pdf/10.1043/0003-B2

[17] Sosa FA, Graber TM, Muller TP. Postpharyngeal lymphoid tissue in Angle Class I and Class II malocclusions. Am J Orthod. [Internet] 1982; 81: 299-309. Available from: http://www.sciencedirect.com/science/article/pii/0002941682902160. http://dx.doi.org/10.1016/0002-9416(82)90216-0

[18] Endo T, Abe R, Kuroki H, Kojima K, Oka K, Shimooka S. Cephalometric evaluation of maxillary sinus sizes in different malocclusion classes. Odontol. [Internet] 2010; 98: 65-72. Available from: http://search.proquest.com/docview/809943966?accountid=7398

[19] Ceylan I, Oktay H. A study on the pharyngeal size in different skeletal patterns. Am J Orthod Dentofacial Orthop. [Internet] 1995; 108: 69-75. Available from: http://www.ajodo.org/article/S0889-5406(95)70068-4.

http://dx.doi.org/10.1016/S0889-5406(95)70068-4

[20] De Freitas MR, Alcazar NM, Janson G, De Freitas KM, Henriques JF. Upper and lower pharyngeal airways in subjects with Class I and Class II malocclusions and different growth patterns. Am J Orthod Dentofacial Orthop. [Internet] 2006; 130: 742-745. PMid: 17169736. Available from: http://www.ajodo.org/article/S0889-5406(06)01024-9/pdf. http://dx.doi.org/10.1016/j.ajodo.2005.01.033

[21] Paul JL, Nanda RS. Effect of mouth breathing on dental occlusion. Angle Orthod 1973; 43: 201-206. PMid: 4512000.

[22] Takemoto Y, Saitoh I, Iwasaki T, Inada E, Yamada C, Iwase Y, et al. Pharyngeal airway in children with prognathism and normal occlusion. Angle Orthod. [Internet] 2011; 81: 75-80. PMid: 20936957. Available from: http://www.angle.org/doi/pdf/10.2319/013010-65.1. http://dx.doi.org/10.2319/013010-65.1

[23] Ucar FI, Uysal T. Orofacial airway dimensions in subjects with Class I malocclusion and different growth patterns. Angle Orthod. [Internet] 2011; 81: 460-468. PMid: 21299381. Available from: http://www.angle.org/doi/pdf/10.2319/091910-545.1. http://dx.doi.org/10.2319/091910-545.1

[24] Pillar G, Shehadeh N. Abdominal fat and sleep apnea: the chicken or the egg? Diabetes Care. [Internet] 2008; 31 Suppl 2:S303-309. PMid: 18227501. Available from: http://care.diabetesjournals.org/content/31/Supplement_2/S303.full.pdf+html. http://dx.doi.org/10.2337/dc08-s272

[25] Niimi A, Matsumoto H, Takemura M, Ueda T, Chin K, Mishima M. Relationship of airway wall thickness to airway sensitivity and airway reactivity in asthma. Am J Respir Crit Care Med. [Internet] 2003; 168: 983-988. PMid: 12829452. Available from: http://www.ncbi.nlm.nih.gov/pubmed/12829452. http://dx.doi.org/10.1164/rccm.200211-1268OC

[26] Tezer MS, Tahamiler R, Canakcioglu S. Computed tomography findings in chronic rhinosinusitis patients with and without allergy. Asian Pac J Allergy Immunol. [Internet] 2006; 24: 123-127. PMid: 17136877. Available from: http://apjai.digitaljournals.org/index.php/apjai/article/viewFile/183/181

[27] Ogawa T, Enciso R, Shintaku WH, Clark GT. Evaluation of cross-section airway configuration of obstructive sleep apnea. Oral Surg Oral Med Oral Pathol Oral Radiol Endod. [Internet] 2007; 103: 102-108. PMid: 17178502. Available from: http://www.ncbi.nlm.nih.gov/pmc/articles/PMC1868407/pdf/nihms15626.pdf. http://dx.doi.org/10.1016/j.tripleo.2006.06.008

[28] Liu JB, Liu LY, Xie MQ, Feng ZJ, Lu X, Li XH, et al. Morphological study of adenoid by endoscopy and its clinical significance. Zhonghua Er Bi Yan Hou Tou Jing Wai Ke Za Zhi. [Internet] 2007; 42:437-442. PMid: 17702419. Available from: http://www.ncbi.nlm.nih.gov/pubmed/17702419 